Quebec Cooperative Study of

Friedreich's Ataxia.

\title{
Friedreich's Ataxia: Preliminary Results of some Genealogical Research
}

\author{
A. BARBEAU, M. LE SIEGE, G. BRETON, R. COALlIER AND J. P. BOUCHARD
}

\begin{abstract}
SUMMARY: A preliminary genealogical investigation of all the known ancestors from the year 1608 of 4 apparently unrelated French Canadian kindreds with Friedreich's at axia reveals that the original ataxia gene in the province of Quebec was present within a core of no more than 10 families living in Quebec City in the mid-1600's.
\end{abstract}

RESUMÉ: Une étude généalogique préliminaire de tous les ancêtres connus jusqu'en 1608 de quatre familles Canadiennes-Françaises apparemment non reliées mais souffrant d'ataxie de Friedreich, a montré que le gène original d'ataxie dans la province de Québec était présent parmi un noyau maximum de 10 familles vivant dans la ville de Québec vers le milieu du l7e siècle.

From the Clinical Research Institute of Montreal and l'Hópital de l'Enfant-Jésus, Quebec City.

Reprint requests for the complete supplement on Friedreich's ataxia to: Dr. André Barbeau, Clinical Research Institute of Montreal, 110 Pine Avenue West, Montreal, H2W 1R7 Quebec, Canada.

\section{INTRODUCTION}

As demonstrated in the previous paper, all cases of ataxia studied in this cooperative study are considered autosomal recessive. This is in contradiction to the findings of Bell and Carmichael (1939) who found a dominant form, albeit in rare instances. In a study of a large American kindred, Schut $(1950,1951)$ had also shown that a family with dominantly inherited spinocerebellar degeneration included some instances of typical Friedreich's ataxia. Because a dominant form of spinocerebellar degeneration is frequent in the Province of Quebec (see subjects and methods), one question raised early in our study was the possible link between that large kindred and our cases of Friedreich's ataxia. Another problem was whether there is a single disease in all our typical cases (Group I) or whether the same phenotype can mask a number of heterogeneous entities. Studying the genealogical background of our kindreds helps solve these questions. The Province of Quebec is ideal for such a task because most of its inhabitants of French extraction are descendants from an original stock of $60-70,000$ immigrants to New France before 1760 ; because of its very high consanguinity rate in the first generations, and finally because church records are mostly intact and available. Therefore, a genealogical search for any common ancestors was included in the protocol of the cooperative study. The present report is incomplete and fragmentary but it should help clear the way for further studies.

\section{SUBJECTS AND METHODS}

The comparison kindred which we attempted to link had been studied in two phases, first by Drs. Raymond Robillard and Jean-Marc St-Hilaire of Montreal (1960-1965) and later by Barbeau (1970-1975). This kindred with a dominant form of spinocerebellar ataxia originated, as far as we could trace from interviews and personal examinations, from a Mont-Louis family in the Gaspé Peninsula in the late 18th century. It was also known that branches of this kindred had lived in Acadia (New Brunswick) and some descendants had emigrated to Louisiana. We are reliably informed that ataxia is a common occurrence among Cajuns of that state.

In the course of the genetic analysis we enquired as to the names. places of birth and death of the ancestors as far back as could be remembered by the oldest members of each family. The Public Archives in Quebec, Trois-Rivières, Montreal and a number of smaller municipalities supplied records to 1750. In this search we were helped by cooperation of active members of "La Société de Généalogie Canadienne-Française", and by students employed by the "Association Canadienne de l'Ataxie de Friedreich" on a Local Initiative Project. Subsequent investigation into earlier generations was done with the help of two invaluable documents: "Le Dictionnaire Généalogique des Familles Canadiennes", C. Tanguay, Editions Elysée; and "Le Dictionnaire National des Canadiens-Français 1608-1760", the latter published by l'Institut Généalogique Drouin in a limited edition.

Because this research had a low priority and was done in large part as a hobby, we completed the investigation of only 4 of the 12 kindreds studied at the Hôtel-Dieu Hospital, 
TABLE 1

Common Ancestors to 4 Kindreds of Ataxia

\begin{tabular}{|c|c|c|c|}
\hline $\begin{array}{l}\text { Names of Early } \\
\text { Common Ancestors }\end{array}$ & Site of Marriage & Local Habitation & Site of Origin in France \\
\hline $\begin{array}{l}\text { Jean Aymard } \\
\text { Marie Bineau }\end{array}$ & - & $\begin{array}{l}\text { Québec } \\
\text { La Rochelle }\end{array}$ & Poitou \\
\hline $\begin{array}{l}\text { Gervais Bisson } \\
\text { Marie Lereau }\end{array}$ & - & Québec & Maine \\
\hline $\begin{array}{l}\text { Jean de Noyon } \\
\text { Marie Chauvin }\end{array}$ & Trois-Rivières & $\begin{array}{l}\text { Dearfield (N.-A.) } \\
\text { Boucherville }\end{array}$ & $\begin{array}{l}\text { St-Pierre de Rouen } \\
\text { (Normandie) } \\
\text { Normandie }\end{array}$ \\
\hline $\begin{array}{l}\text { Mathieu Choret } \\
\text { Sébastienne Veillon }\end{array}$ & $\begin{array}{l}\text { N-D. de Cogne } \\
\text { (La Rochelle) }\end{array}$ & $\begin{array}{l}\text { Québec } \\
\text { Beauport } \\
\text { Ste-Famille (Ile d'Orléans) }\end{array}$ & $\begin{array}{l}\text { La Rochelle (Aunis) } \\
\text { Saintes (Angoumois) }\end{array}$ \\
\hline $\begin{array}{l}\text { Pierre Loignon } \\
\text { Françoise Roussin }\end{array}$ & Québec & Ste-Famille (lle d'Orléans) & Perche \\
\hline $\begin{array}{l}\text { Robert Drouin } \\
\text { Marie Dubois }\end{array}$ & - & Québec & Perche \\
\hline $\begin{array}{l}\text { Charles Sévestre } \\
\text { Marie Pichon }\end{array}$ & - & Québec & Paris (Ile-de-France) \\
\hline $\begin{array}{l}\text { Jean Guyon } \\
\text { Mathurine Robin }\end{array}$ & - & Québec & Perche \\
\hline $\begin{array}{l}\text { Noël Morin } \\
\text { Hélène Desportes }\end{array}$ & Québec & Québec & $\begin{array}{l}\text { Ile-de-France } \\
\text { Lisieux (Normandie) }\end{array}$ \\
\hline $\begin{array}{l}\text { Léonard Leblanc } \\
\text { Marie Riton }\end{array}$ & Québec & Québec & Marche \\
\hline
\end{tabular}

but other families are being studied. A complete family tree, in French Canada, goes back 10 to 13 generations to the early days of the colony (1608-1700). In general, for the 4 families studied, we were able to trace 12 generations (an average of 2,048 names of "primary" possible progenitors per family). Many names appear a number of times, because of consanguinity in the later generations.

Once the 4 trees were completed on special large sheets, an index-card was made for each name recorded in all known generations in Canada, for each family. In this way, names of ancestors appearing in more than one family could be determined, to help pin-point consanguinous marriages. Names appearing in all 4 families were prepared to list all their possible descendants. Links between the 4 original families were thus delineated.

\section{RESULTS AND DISCUSSION}

Many difficulties (such as incomplete records, occasional illegitimate births, errors in transcription or spelling from the original documents) and lack of time precluded complete ancestral trees on all the kindreds included in our cooperative survey. Thus the present summary is only a progress report of an investigation which will take many years to conclude. To date we have traced all the Canadian ancestors of four kindred (herewith labelled kindreds $A$ to D). A total of 8,260 names of ancestors were obtained on index cards showing a large number of links, and consanguinous marriages. This is illustrated in Figures 1, 2 and 3.

For example, in Figure 1 there are at least 14 consanguinous marriages. Each time this occurs the risk of transmission of a given gene is multiplied. In this geographically and linguistically isolated population there are so many possible ways for a given patient to be traced back to the common ancestor that it is almost impossible to know the actual transmittors of the abnormal gene.

We have, of the thousands of possible ancestral couples, identified 10 marriages that appear in all 4 kindreds investigated (Table 1). For each of these common "primary" ancestors, trees such as the one illustrated in Figure 1 could be drawn, further complicating the situation (when we had completed 3 kindreds, there were 22 common ancestral couples). It is hoped that the addition of further complete kindreds will permit us to identify the one common ancestral couple who may even have lived in France before 1608 (date of establishment of Quebec City). At the present time we are unable to do so, but some common characteristics of the "primary" ancestral couples permit us to be fairly confident that 


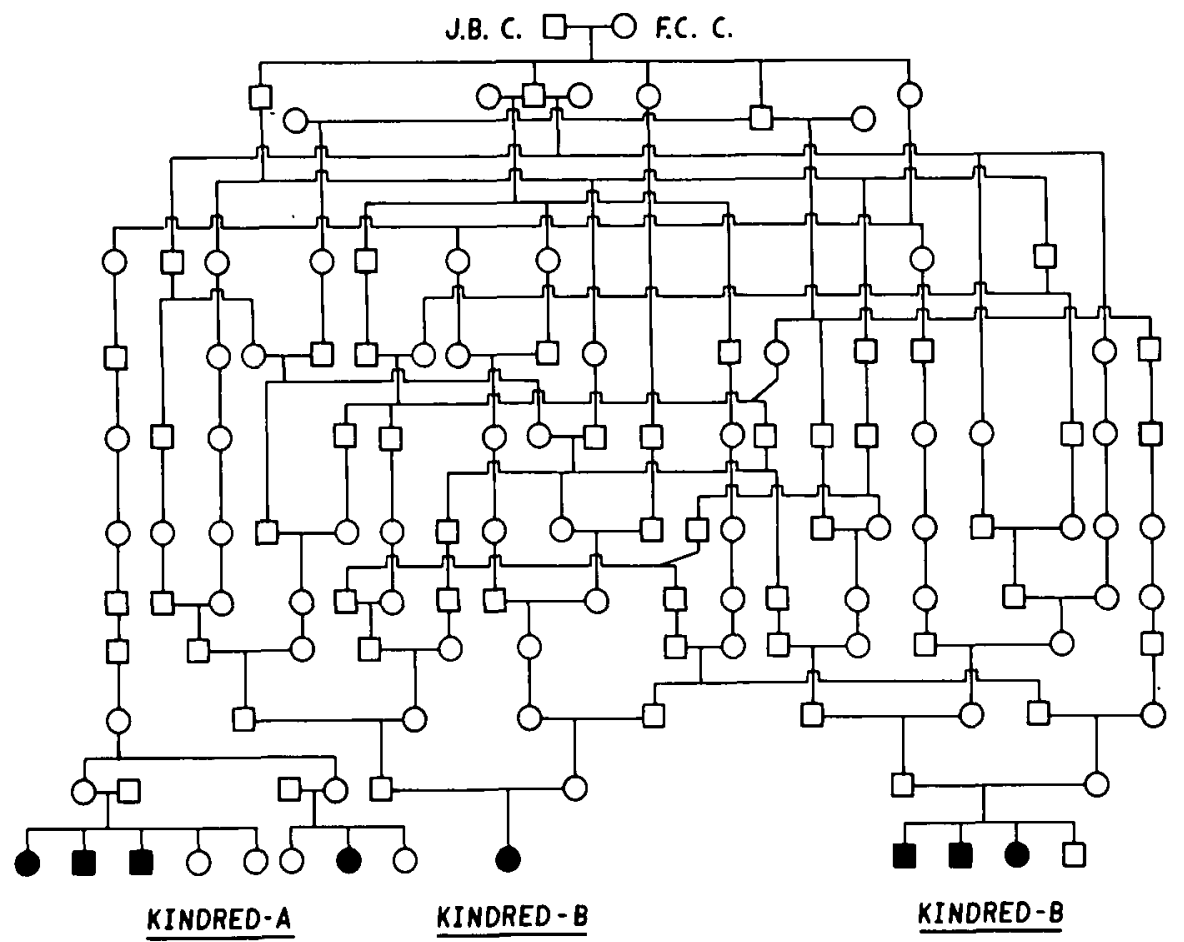

Figure I - An example of many consanguinous marriages in a French Canadian family with typical Friedreich's ataxia, and of the links between kindreds A and B. Open square $=$ normal male, solid square $=$ ataxic male, open circle $=$ normal female, solid circle $=$ ataxic female.

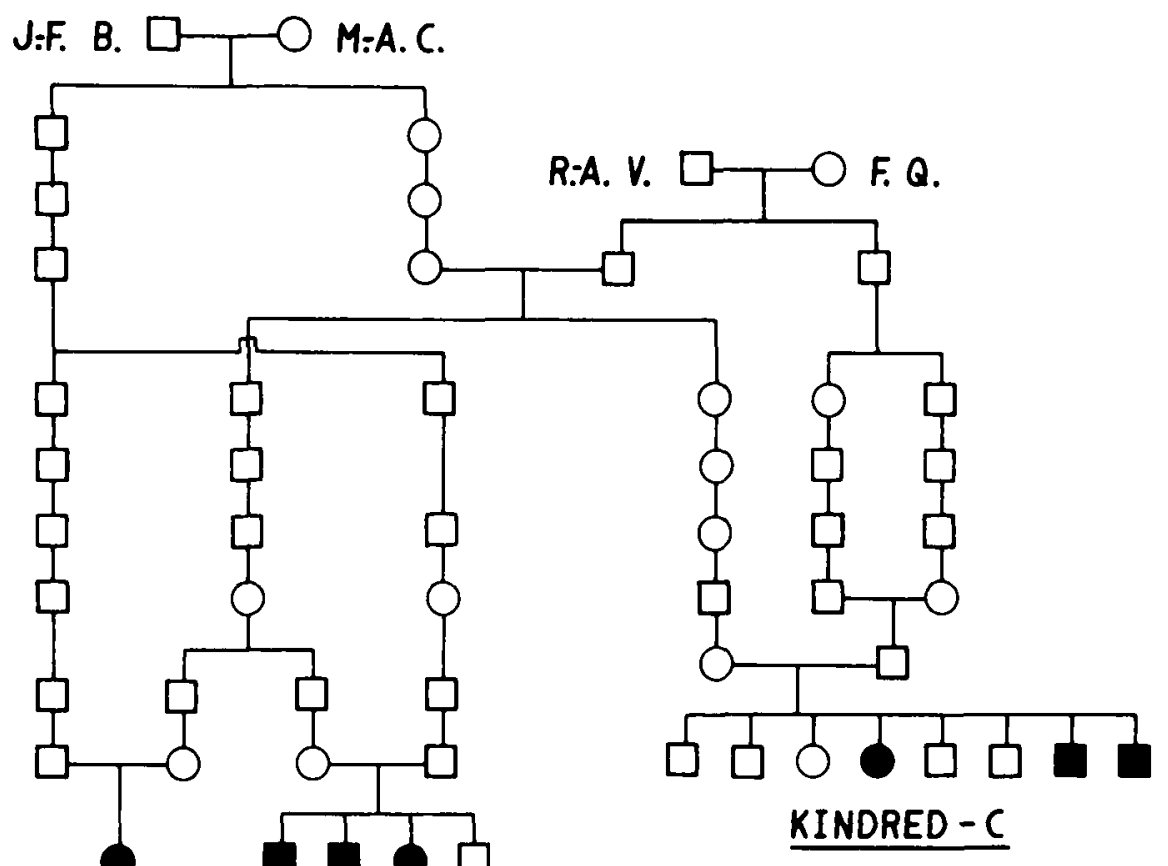

KINDRED - B

Figure 2 - Possible links between kindreds B and C with Friedreich's ataxia in French Canada. Open square $=$ normal male, solid square $=$ ataxic male, open circle $=$ normal female , solid circle $=$ ataxic female . there is one common genetic source to at least 4 of our typical Friedreich's ataxia kindreds. All couples and their first generation descendants, although originating from diversified regions of France, lived in Quebec City between 1615 and 1680 , when the immigrant population of "La Nouvelle France" numbered 3,802 . It is thus highly likely that they all knew each other quite well. This is further attested to by the fact that within the 3 subsequent generations it was possible to show marriages between descendents that linked at least 9 of the 10 "primary" ancestral couples.

In conslusion, we can state with some degree of certainty that the original "Friedreich's ataxia gene" in Quebec, at least for the kindreds included in our cooperative survey, must have been present within a core of 10 families living in Quebec City in the mid-1600's (Table I for list). For each of these 10 "primary" couples it can be shown that the gene could have descended directly to the patients included in our survey (Figure 4). Further investigation is necessary to correctly identify the actual common ancestor to all our typical cases of Friedreich's ataxia, and to show whether there is a link with the dominant form of spinocerebellar degenerations also identified in Quebec. All that can be stated now is that the family surname of the earliest identified case of the dominant form does exist amongst the descendents of some of the "primary" couples. If a link can be discovered, this would complicate genetic analysis of the phenotypic expressions of the ataxias. Until all our kindreds have been studied, it will be impossible to use the genealogical argument to decide whether we are dealing with one or many disease entities. Nevertheless, we feel that if this research approach is eventually successful, it will be one of the most powerful instruments for the understanding and nosological classification of the ataxias. 


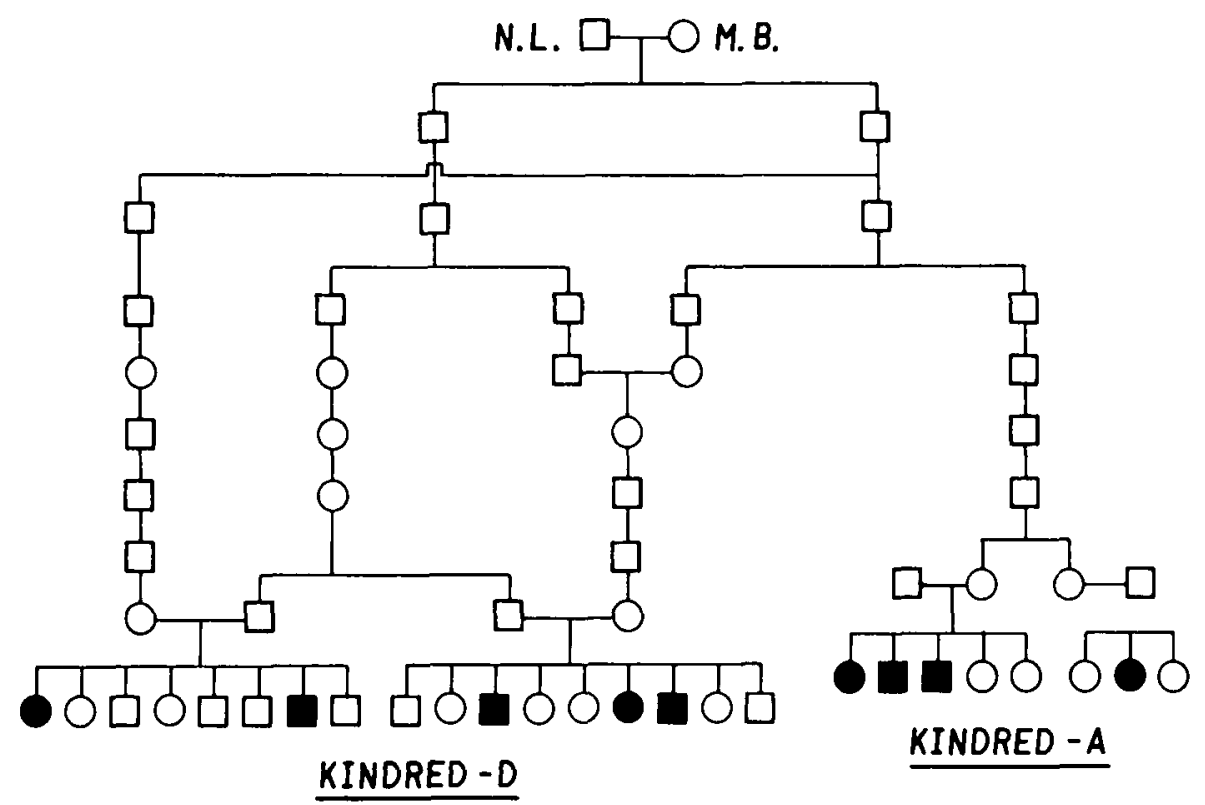

Figure 3 - Possible links between kindreds A and D with Friedreich's ataxia in French Canada. Open square $=$ normal male. solid square $=$ ataxic male, open circle $=$ normal female, solid circle $=$ ataxic female.

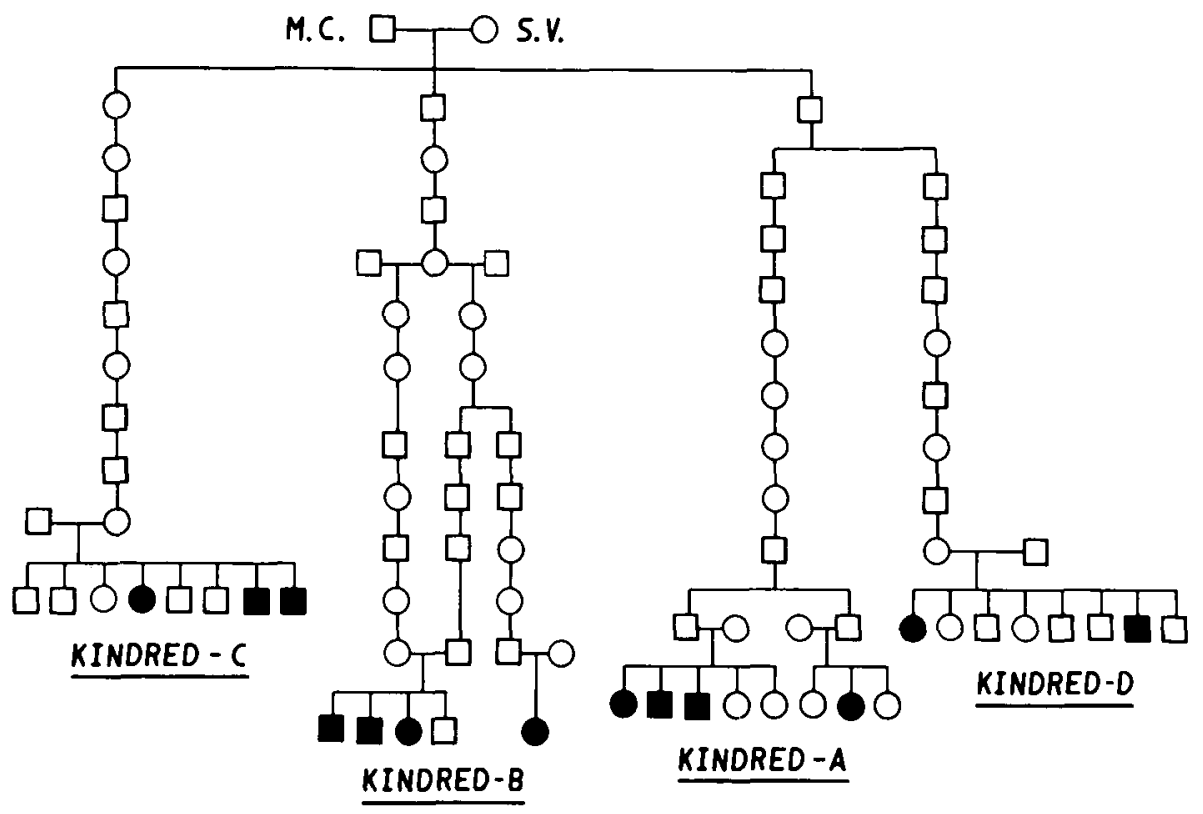

Figure 4 - One of 10 possible pairs of common ancestors to the 4 studied kindreds with Friedreich's ataxia in French Canada. Open square $=$ normal male, solid square $=$ ataxic male, open circle $=$ normal female, solid circle $=$ ataxic female.

\section{ACKNOWLEDGEMENTS}

These studies were supported by L'Association Canadienne de l'Ataxie de Friedreich, la Fondation Jeanne-Mance, and a Local Initiative Project. The contribution of Dr. Eva Andermann for one of the kindreds is gratefully acknowledged, as well as the help of many members of La Société de Généalogie Canadienne-Française.

\section{REFERENCES}

BELL, J. M., and CARMICHAEL, E. A. (1939). On hereditary ataxia and spastic paraplegia. In: Treasury of Human Inheritance, Vol. 4, Cambridge Press, London, pp. 141-284.

SCHUT, J. W. (1950). Hereditary ataxia: Clinical study through 6 generations. Arch. Neurol. and Psychiatry, 63, 535-568.

SCHUT, J. W. (1951). Hereditary ataxia: A survey of certain clinical pathologic and genetic features with linkage data on five additional hereditary factors. Amer. J. Human. Genet., 3, 93-110. 